\title{
ASSESSMENT OF THE TERRITORIAL DEVELOPMENT OF AGRICULTURAL LAND USE IN UKRAINE
}

Kupriyanchik I., PhD ., Associate Professor, National University of Life and

Environmental Sciences of Ukraine, Kyiv, kupriyanchik@ukr.net

Butenko E., PhD ., Associate Professor, National University of Life and Environmental Sciences of Ukraine, Kyiv, evg_cat@ukr.net

Kolisnyk G., Associate Professor, National University of Life and Environmental Sciences of Ukraine, Kyiv, kolisnyk_g@nubip.edu.ua

The article explores the prospects of territorial development of agricultural land use in Ukraine. It has been established that land resources, namely agricultural lands, are one of the main agricultural production resources required for crop production, including livestock production. It is concluded that the efficiency of agricultural land, distribution between land users, depends on the efficiency of agricultural production as a whole.

It is emphasized that the emphasis of the state policy in the agrarian sphere on the accelerated and insufficiently motivated privatization of land and property caused the destruction of large commodity agricultural production, but was not effective in the formation of new productive production forms.

It was emphasized that with the change of economic forms the boundaries of land use, the size of land were changed, which leads to difficulties in their cultivation and implementation of measures for their protection. For example, in connection with the creation of a large number of farms, there was a significant fragmentation of land, which in turn led to excessive parceling of land and, in particular, to a decrease in the efficiency of agricultural production.

Keywords: economic development, environmental factors, territorial development, agricultural land use, agricultural land. 
Formulation of the problem. The study of the features of agricultural development, its land use, as well as the territorial organization in modern conditions, characterized by changing socio-economic relations in society, the transition to a market economy and restoration of private property, is necessary to rationalize further development and increase the stable efficiency of agricultural production.

Land resources, namely farmland, are one of the main agricultural production resources required for crop and livestock production. Efficiency of agricultural land, distribution between land users, depends on the efficiency of agricultural production as a whole. Therefore, the problem of assessing the state of territorial development of agricultural land use in Ukraine has been reflected in numerous scientific publications.

Analysis of recent research and publications. The works of well-known Ukrainian economists are devoted to the research of the problem of agricultural land use. A great contribution to the development of theoretical and methodological research and the development of practical recommendations on the formation of agricultural land use were made by O. Vinskaya, J. Dorosh, Sh. Ibatullin, O. Popova, N. Sirenko, M. Khvesik, O. Khodakivska, N. Shibaeva, O. Shkuratov and others. In particular, the peculiarities of the current state of implementation of the Common Agrarian Policy of the European Union have been investigated [1]; the state and prospects of capitalization of land resources of the region were investigated [2]; an organizational and economic mechanism for ensuring the production of environmentally friendly agricultural products has been developed [3]; identified new EU agricultural policy priorities for 2014-2020 [4]; and strategic guidelines for the development of Ukraine's agrosphere [6]; specific conditions for managing the strategy of innovative development of the agrarian sector of the Ukrainian economy have been identified [5]; the modern dimension and prospects of development of greening of agricultural lands [7] by specifying ecological and economic imperatives [9]; the evolution of the common agricultural policy of the European Union has been traced[8]. However, the issue of specifying problems and prospects of territorial 
development of agricultural land use in Ukraine has not been properly reflected in scientific research.

The purpose of the research. Assess the state of territorial development of agricultural land use in Ukraine.

\section{Results of the study and their discussion.}

Characteristic features of the modern stage of human development are the rapid and exhausting use of non-renewable species of natural resources and the exploitation of renewable resources at a speed that exceeds their recovery. The use of land resources in agriculture is no exception. The main cause of a number of problems in the system of agricultural land use is the transformation of land relations of Ukraine to a market type without effective mechanisms of reform. The emphasis of state policy in the agricultural sector on the accelerated and insufficiently motivated privatization of land and property caused the destruction of large commodity agricultural production, but was not effective in the formation of new productive production forms. Over 28 years of land reform in Ukraine, the area of agricultural land used in agricultural production has decreased by 8.6 million hectares. There was an unacceptable grinding of the structure of agricultural production. Today, as a result of the blockage of the private agricultural land market, there is an increasing tendency to create unbalanced agricultural land uses. In addition, the use of land for the production of agricultural products is mainly conducted not by the owner, but by tenants, which leads to the depletion of ("foreign") land.

With the adoption of the Verkhovna Rada of the USSR on December 18, 1990, the Resolution "On Land Reform", the reform of land relations and the formation of market relations in the countryside began. On the basis of a number of normative acts, in 1992-1995 a number of organizational measures were implemented to reform the system of land relations (land demarcation, privatization of lands by transferring them to collective and private property, monetary valuation of agricultural lands, formation of the land market and its infrastructure. However, no ecological and economic justification of the redistribution of land-territorial resources 
in the country was conducted on the basis of relevant national and regional forecast developments. Imperfect reforming practices have deepened the economic imbalance of the land fund, caused a decrease in the efficiency of land use and protection, the ability to naturally restore soil fertility. The market circulation of privatized land plots was not economically and infrastructurally prepared.

New organizational forms of rural economy were created mainly in 2000 on a significantly weakened production base, without state financial support, mortgage lending, and agrarian market infrastructure. When changing the organizational structure, the task was not to maintain the existing concentration of agricultural production and to implement measures for land consolidation in necessary cases. According to the new Land Code of Ukraine (2001), it became possible to create a legal and organizational environment for citizens to realize land ownership rights and to put agricultural land into economic circulation. However, the new Land Code has remained largely a temporary normative act, which defines norms aimed at solving current problems of land reform rather than regulating land relations in a market economic environment [1, p. 5].

One of the tasks of land reform was to become a private owner, a landowner. The state has lost its monopoly ownership of land. As of 01.01 .2018 , about $84 \%$ of agricultural land is privately owned.

Agricultural land accounts for almost $68.9 \%$ (41.6 million hectares) of Ukraine's land. The plowed up of agricultural land is the highest in the world. It reaches $78.2 \%$ of the average in Ukraine. However, in the process of land reform, there has been a significant reduction in the area of agricultural land, including arable land. If in 1990, 38.7 million hectares of agricultural land were used in agricultural production (92\% of their total area), in 2019 - 30 million hectares (72\% of their total area) $[4$, p. 94] . One of the tasks of land reform was to become a private owner, a landowner. The state has lost its monopoly ownership of land. As of 01.01.2018, about $84 \%$ of agricultural land is privately owned.

As a result of the land reform in Ukraine, a number of new market-type agricultural productions have emerged. As of January 1, 2018, about 171 thousand 
new agricultural formations were created. $49.1 \%$ of these lands are concentrated in commercial companies, $20.0 \%$ in farms, $16.0 \%$ in private enterprises, $4.6 \%$ in industrial cooperatives, $2.6 \%$ in state-owned enterprises, and in other enterprises forms of management $-7.7 \%$ [3, p. 183].

With the change of economic forms, the boundaries of land use, the size of land have changed, which leads to difficulties in their balanced cultivation and implementation of measures for their protection. In particular, due to the creation of a large number of farms, there has been considerable fragmentation of land, which in turn leads to excessive parceling of land. This in turn leads to a decrease in the efficiency of agricultural production.

Modern land use of Ukraine does not meet the requirements of balanced nature management, because ecologically permissible ratio of arable land, natural forage lands, forest plantations has been violated, which adversely affects the sustainability of agricultural landscapes [6, p. 12]. Thus, the area of conditionally stable lands decreased: the area of deposits decreased by 109.1 thousand hectares, hayfields - by 18 thousand hectares, pastures - by 39.4 thousand hectares, perennial plantations - by 4 thousand hectares [6, p. 12]. At the same time, the area of arable land increased by 24.6 thousand hectares, which does not contribute to the ecological stability of the territory of Ukraine. Also, there was an increase in the area of land under construction by 45 thousand hectares, open wetlands by 13.9 thousand hectares. However, it is worth noting a positive tendency to increase forest area.

During the period from 1990 to 2018, some changes occurred in the structure of acreage of basic crops. The share of cereals in the total acreage increased from 45.0 in 1990 to $57 \%$ in 2018 , the share of sunflower increased from 5.0 to $17 \%$, which is explained by the profitability of growing these crops. However, increasing the acreage of these crops while reducing the proportion of legumes from 9.8 to $3.0 \%$ in the composition of cereals and fodder crops from 37.0 to $15.4 \%$ in the total acreage has no positive effect on the conservation of soil fertility and improvement of their quality [5, p. 18]. As a result, scientifically based crop rotations, anti-erosion organization of territories, introduction of monoculture and, as a consequence, 
deterioration of agricultural production quality and development of land degradation are disrupted.

It is known that land relations in Ukraine are governed by the Land Code, according to which land use in Ukraine is paid (Article 206 of the Land Code), and the payment of land, according to the Tax.

Analyzing the system of land payments in Ukraine, it becomes apparent that it does not correspond to the current realities of economic regulation of land relations and management of land resources.

Land payments cover about one-third of the land fund, and today payment rates are low. There are a large number of exempts from payments, land payments are not used for the intended purpose. Land payment forms are limited. Therefore, the current system of land payments in Ukraine, to date, does not provide reasonable withdrawal and distribution of land rent from the use of land resources in the interests of the national economy of Ukraine [2].

In the process of land reform, the transition to various forms of land ownership was carried out and a free redistribution of land was carried out for the benefit of citizens. However, in the country, as of today there is no complete land cadastre. However, the land cadastre is an information base for land management, regulation of land relations, taxation and investment for the purpose of balanced use and protection of land.

Conclusions. It is determined that a significant cause of a number of problems in the system of agricultural land use is the transformation of land relations in Ukraine to a market type in the absence of effective mechanisms of reform. In the process of land relations reform, the following environmental and economic problems of agricultural land use have arisen: legal uncertainty of land use regulation due to lack of zoning mechanisms; reduction of the area of agricultural land used by producers; growing parceling and scattering of farmland as a result of stocking; violation of the ecologically acceptable ratio of arable land; soil degradation and contamination; lack of effective economic incentives and sanctions as levers of land management; imperfection of the land legislation and infrastructure of the 
agricultural land market; imperfect system and mechanism of distribution of payments for use of land resources; insufficient number of land management works on rationalization of land use and land protection.

\section{References}

1. Vinska, O. Y. (2010). Osoblyvosti suchasnoho stanu realizatsii Spilnoi Ahrarnoi Polityky Yevropeiskoho Soiuzu. [Features of the current state of implementation of the Common Agricultural Policy of the European Union]. Ekonomichnyi prostir - Economic space, 40, 5-19 [in Ukrainian]

2. Ibatullin SH.I., Khvesyk M.A., Dorosh Y.M. (2014). Stan ta perspektyvy kapitalizatsiyi zemel $\square$ nykh resursiv rehionu v konteksti staloho rozvytku Ukrayiny. [State and prospects of capitalization of land resources of the region in the context of sustainable development of Ukraine: monograph] -Kyiv. - 198 p. [in Ukrainian]

3. Sava, A. P., Sydoruk, B. O., Oliinyk, O. R., \& Dovhan, S. V. (2014). Orhanizatsiino-ekonomichnyi mekhanizm zabezpechennia vyrobnytstva ekobezpechnoi silskohospodarskoi produktsii. [Organizational and economic mechanism of ensuring of environmentally safe agricultural production]. Ternopil, Ukraine: Krok, 263 [in Ukrainian]

4. Popova, O. L. (2013). Novi priorytety Spilnoi ahrarnoi polityky YeS na 2014-2020 roky: stratehichni oriientyry dlia rozvytku ahrosfery Ukrainy [New priorities of the EU Common Agricultural Policy for 2014-2020: strategic landmarks for the development of the agrosphere of Ukraine]. Ekonomika APK - Economy of agroindustrial complex,12,89-96 [in Ukrainian].

5. Sirenko, N. M. (2010). Upravlinnia stratehiieiu innovatsiinoho rozvytku ahrarnoho sektora ekonomiky Ukrainy [Management of the Strategy of Innovative Development of the Agricultural Sector of the Ukrainian Economy]. Mykolaiv

6. Lupenko, Yu. O., \& Mesel-Veseliak, V. Ya. (Eds.) (2012). Stratehichni napriamy rozvytku silskoho hospodarstva Ukrainy na period do 2020 roku [Strategic directions of development of agriculture in Ukraine for the period till 2020]. Kyiv: Natsionalnyi naukovyi tsentr «Instytut ahrarnoi ekonomiky». 
7. Khodakivska, O. V. (2011). Ekolohizatsiia silskohospodarskykh zemel: suchasnyi vymir ta perspektyvy rozvytku [Ecologization of agricultural land: modern dimension and development prospects]. Ekonomika APK - Economy of agroindustrial complex, 10, 28-36.

8. Shybaieva, N. V., \& Kviatko, T. M. (2015). Evoliutsiia spilnoi ahrarnoi polityky YeS [Evolution of the EU Common Agricultural Policy]. Visnyk Kharkivskoho natsionalnoho tekhnichnoho universytetu silskoho hospodarstva imeni Petra Vasylenka Bulletin of the Kharkov National Technical University of Agriculture, 162, 306-315.

9. Shkuratov, O. I., Chudovska, V. A., \& Vdovychenkov, A. V. (2015). Orhanichne silske hospodarstvo: ekolohoekonomichni imperatyvy rozvytku.[Organic agriculture: ecological and economic imperatives of development]. Kyiv: DIA.

Купріянчик І.П., Бутенко Є.В., Колісник Г.М.

ОЦНКА СТАНУ ТЕРИТОРІАЛЬНОГО РОЗВИТКУ СІЛЬСЬКОГОСПОДАРСЬКОГО ЗЕМЛЕКОРИСТУВАННЯ В УКРАЇНІ

У статті досліджено питання перспективи територіального розвитку сільськогосподарського землекористування в України. Встановлено, щэо земельні ресурси, а саме сільськогосподарські угіддя є одними з основних ресурсів сільськогосподарського виробнищтва, необхідних для отримання рослинницької продукції, у тому числі і для виробництва тваринницької продукиії. Підсумовано, щзо від ефективності використання сільськогосподарських угідь, розподілу між землекористувачами, залежить ефективність сільськогосподарського виробництва в цілому.

Підкреслено, щзо акиентування державної політики в аграрній сфері на прискореній і недостатньо вмотивованій приватизації землі і майна викликало руйнування великого товарного сільськогосподарського виробництва, однак не було ефективним в утворенні нових продуктивних виробничих форм.

Наголошено, щзо зі зміною форм господарювання змінилися межі землекористування, розміри земельних ділянок, щэо призводить до труднощів в 
їх обробітку $i$ здійсненні заходів щуодо їх охорони. Приміром, у зв'язку зі створенням великої кількості фермерських господарств, відбулося значне подрібнення земельних ділянок, щзо в свою чергу призвело до надмірної парцеляції земель ц̌, зокрема, до зменшення ефективності аграрного виробницчтва.

Ключові слова: економічний розвиток, екологічні фактори, територіальний розвиток, сільськогосподарське землекористування, сільськогосподарські угіддя.

\section{Куприянчик И.П., Бутенко Е.В., Колесник Г.Н.}

\section{ОЦЕНКА СОСТОЯНИЯ ТЕРРИТОРИАЛЬНОГО РАЗВИТИЯ} СЕЛЬСКОХОЗЯЙСТВЕННОГО ЗЕМЛЕПОЛЬЗОВАНИЯ В УКРАИНЕ В статье исследован вопрос перспективы территориального развития сельскохозяйственного землепользования в Украине. Установлено, что земельные ресурсы, а именно сельскохозяйственные угодья являются одними из основных ресурсов сельскохозяйственного производства, необходимьх для получения растениеводческой продукции, в том числе и для производства животноводческой продукиии. Подведень, что от эффективности использования сельскохозяйственных угодий, распределения между землепользователями, зависит эффективность сельскохозяйственного производства в цүелом.

Подчеркнуто, что акцентирование государственной политики в аграрной сфере на ускоренной и недостаточно мотивированного приватизации земли и имущчества вызвало разрушения крупного товарного сельскохозяйственного производства, однако не было эффективнылм в образовании новых производительных производственных форм.

Отмечено, что с изменением форм хозяйствования изменились границьь землепользования, размеры земельных участков, что приводит к трудностям в их обработки и осущуествлении мероприятий по их охране. К примеру, в связи с созданием большого количества фермерских хозяйств, прочзошло 
значительное измельчения земельньх участков, в свою очередь привело к чрезмерной парцฺелляциюю земель и, в частности, к уменьшению эффективности аграрного производства.

Ключевые слова: экономическое развитие, экологические факторы, территориальное развитие, сельскохозяйственное землепользование, сельскохозяйственные угодья. 